\title{
LIBERALIZMUS, OBČIANSKE PRÁVA A EKONOMICKÁ NESLOBODA (K TUGENDHATOVEJ KONCEPCII LUUSKÝCH PRÁV V KONTEXTE LUDÍ SO ZDRAVOTNÝM ZNEVÝHODNENÍM)
}

\author{
MARTIN MURÁNSKY, Filozofický ústav Slovenskej akadémie vied, Bratislava, SR
}

MURÁNSKY, M.: Liberalism, Civil Rights and Economic Unfreedom (On the Tugendhat's Concept of Human Rights in the Context of People with Disabilities) FILOZOFIA, 74, 2019, No 8, pp. $593-607$

The aim of the paper is to explain the normative ambivalent interconnection between civil rights and economic rights based on the example of people with disabilities. The article starts with the reference to two competing ideals of freedom in the human rights agenda, and the two meanings of the lack of freedom: while the libertarian normative ideal of lack of freedom means coercion by man (F. W. Hayek), the egalitarian liberal understanding of unfreedom is extended to the lack of public capacity to acquire the personal ability to lead autonomous life and to the lack of opportunities to put these abilities into practice. In this case the original meaning of freedom is based on the interpretation of egalitarian dignity as formulated by Kant for the first time. Based on this normative ideal, the study further extends it to Tugendhat's concept of practical autonomy as a socially acquired ability and opportunity to lead an independent life, in the contrast to the one-sided dependency on impersonal, structurally given conditions of life. What practical autonomy in the case of disabled persons demonstrates, is the connection between practical autonomy, human dignity and equal rights, which implies redistribution of public resources for help to self-help. This redistribution does not seem to be in conflict with the rest of human rights, with the serious exception of the right of property. The fate of the human rights agenda, democracy generally, depends on the resolvability of the fundamental conflict between the right of property and the right to live in dignity.

Keywords: People with disabilities - Two normative ideals of freedom - Right of property - Human dignity - Practical autonomy - Tugendhat, E.

Pri rozpracovaní problematiky práv zdravotne znevýhodnených l'udí je legitímne alebo nevyhnutné položit' si otázku, či popri klasických liberálnych občianskych právach netreba hovorit’ aj o sociálno-ekonomických právach človeka tak, ako ich spomínajú 
Články 22 a 23 Všeobecnej deklarácie ludských práv z roku $1948^{1}$ a ako ich d'alej špecifikuje Medzinárodný pakt o hospodárskych sociálnych a kultúrnych právach Organizácie spojených národov. ${ }^{2}$ Hned' na úvod treba povedat', že témou sú väčšinou prípady l'udí, ktorí sú odkázaní na materiálnu a existenčnú pomoc iných l’udí, lepšie povedané spoločnosti. ${ }^{3}$ Tieto práva sa netýkajú primárne tých, ktorí si vedia pomôct' sami, lebo im na to nechýbajú zdroje a prostriedky.

Akým spôsobom možno pochopit' nárok na pomoc pre zdravotne znevýhodnených ako l'udské právo s nárokom na pozitívnu diskrimináciu v zabezpečení zdrojov a príležitostí?

Ernst Tugendhat v nadväznosti na Thomasa Nagela a Anne Gutmann ponúka pre túto štúdiu metodicky záväzné východisko v podobe tézy, podl'a ktorej koncept l'udských práv spája v sebe dva ambivalentné a vzájomne si konkurujúce koncepty slobody. Po prvé, libertariánsky koncept individuálnej slobody prejavu, vierovyznania, politickej slobody a primárne slobody vlastníctva, v ktorom je každý človek, aj zdravotne postihnutý, v princípe sám zodpovedný za svoje dobré alebo zlé postavenie v svete. Tento koncept je zároveň súčast'ou širšieho kultúrneho ideálu individualistickej sebarealizácie stojacej nad verejným dobrom. Druhým konceptom je predstava demokratickej spoločnosti kontrolovanej svojimi občanmi, ktorá vychádza z etiky egalitárnej dôstojnosti a rešpektovania záujmov všetkých jej členov na základe prepojenia slobody s otázkou spravodlivosti. Problém znevýhodneného postavenia jej slabších členov je tu primárne politickou otázkou eliminácie nerovností, ktorej predpokladom je normatívny ideál obmedzovania vlastných záujmov v prospech verejného dobra.

V nasledujúcej štúdii sa chcem sústredit’ na rozpracovanie problematiky zdravotne znevýhodnených l’udí v normatívnej perspektíve nedelitel’nosti občianskych a sociálnych l’udských práv. Po prvé, v oboch konceptoch ludských práv je opakom

\footnotetext{
${ }^{1}$ Podl'a V̌̌eobecnej deklarácie l’udských práv, Článok 22, má každý človek právo na sociálne zabezpečenie a slobodný rozvoj jeho osobnosti. Ďalej podl'a Čl. 23 má tiež (1) právo na prácu, (2) právo na rovnaký plat za rovnakú prácu, (3) životnú úroveň zodpovedajúcu l'udskej dôstojnosti. Dostupné na: https://www.gender.gov.sk/wp-content/uploads/2012/06/UDHRvSVK.pdf

${ }^{2}$ Podl'a Medzinárodného paktu o hospodárskych, sociálnych a kultúrnych právach $\mathrm{v}$ Článku $11 \mathrm{sa}$ uznáva právo každého jednotlivca na primeranú životnú úroveň preňho a jeho rodinu. Pre zdravotne znevýhodnených je tiež osobitne dôležitý Článok 2. 1., podl’a ktorého existuje právo každého na dosiahnutie najvyššej dosiahnutel'nej úrovne fyzického a duševného zdravia. Dostupné na: https://www.amnesty.sk/wp-content/uploads/2012/01/Medzin\%C3\%A1rodn\%C3\%BD-pakt-ohospod\% C3\%A1rskych-soci\%C3\%A1lnych-a-kult\%C3\%BArnych-pr\%C3\%A1vach.pdf

${ }^{3}$ V Dohovore OSN o právach osôb so zdravotným postihnutím (v Preambule) sa doslova uvádza: „Upozorňujúc na skutočnost', že väčšina osôb so zdravotným postihnutím žije v podmienkach chudoby“ sa uznáva „naliehavá potreba riešit’ problém nepriaznivého vplyvu chudoby na osoby so zdravotným postihnutím“. Dostupné na: https://www.employment.gov.sk/files/slovensky/uvod/legislativa/socialna-pomoc-podpora/dohovor-osn-pravach-osob-so-zdravotnym-postihnutim-opcny-protokol-sk-aj.pdf.
} 
slobody človeka istá podoba znevýhodnenia / prekážky vo významne neslobody ako toho, čo mi bráni v uskutočňovaní života podl’a vlastných možností. Existuje v tomto koncepte neslobody dimenzia, ktorá oprávňuje legitimitu širšieho egalitaristického konceptu l'udských práv? Vychádzajúc z toho chceme, po druhé, nanovo upozornit' na Tugendhatov výklad autonómie (dôstojnosti človeka) ako praktickej spôsobilosti samostatného života, ktorý zásadným spôsobom prekonáva jej pôvodne kantovský význam autonómie ako rozumnosti. Pomocou týchto pojmových rozlíšení sa pokúsim nakoniec, po tretie, vyvodit' ich normatívne dôsledky pre komplexný koncept l'udských práv, zahŕňajúci aj sociálne a ekonomické práva, a to z hl’adiska dvoch vzájomne ambivalentných tradícií výkladu základného l’udského práva ako práva na vlastníctvo a práva na život.

\section{Negatívna sloboda (I. Berlin vs. F. W. Hayek)}

Už Immanuel Kant v Metafyzike mravov sformuloval definíciu negatívnej slobody tak, že ju možno pokladat' za záväzný koncept jej libertariánskeho výkladu: ako „nezávislost' od prinucujúcej svojvôle iného, nakol'ko je zlučitel'ná so slobodou každého iného podl'a všeobecného zákona“ (Kant 1797, 237). Človek je podl’a Kanta slobodný vtedy, ked’ môže konat' a žit' podl'a vlastných predstáv v súlade so všeobecným zákonom a v protiklade k životu, ktorý je ovládaný cudzou vôlou. Nesloboda sa aj v libertariánskej tradícii zužuje na osobný vzt’ah človeka k človeku, a predsa je $\mathrm{v}$ tejto zdanlivo jednoznačnej definícii slobody skrytá zásadná dvojznačnost', na ktorú upozornil Ernst Tugendhat (1993, 336 - 363). Prvý význam „negatívnej slobody“ sa opiera o možnost' jej výkladu ako možnosti „osobnej vol'by“ (Isaiah Berlin). Druhý význam vychádza $z$ iného výkladu negatívnej slobody ako neprítomnosti osobného zasahovania (Friedrich W. Hayek). V prvom význame negatívnej slobody teda ide o stotožnenie ,zodpovednosti“ so „slobodnou vol'bou“ tak, ako to reprezentuje enormne vplyvná, hoci eklektická esej Isaiaha Berlina Dva pojmy slobody. V nej sa nachádza aj klúčová myšlienka, ktorá expressis verbis potvrdzuje identitu slobody a vol'by. „Rozsah negatívnej slobody závisí od toho, či mám moc vybrat' si prinajmenšom medzi dvoma alternatívami““ (Berlin 1997, 58). S možnost'ou vol’by medzi dvoma alternatívami Berlin spája politicky slobodnú spoločnost', no zároveň redukuje každú l'udskú situáciu na možnost' vol'by v nej, pokial' človek koná dobrovol'ne a v súlade so zákonom, teda pokial' mu v tom nik iný osobne ani zo strany vlády nebráni.

Čo však so situáciami, kde nejde o politiku, ale o rôzne druhy sociálnej zranitel'nosti človeka? Berlin pozná jednoduchú odpoved'. „Ak by bola moja chudoba nejakým druhom choroby, ktorá mi bráni, aby som si kúpil kúsok chleba [...], podobne ako mi invalidita bráni, aby som behal, [...] potom by táto nemohúcnost', prirodzene, 
nemohla byt' označovaná za nedostatok slobody“ (Berlin 1997, 51). Signifikantné je stotožnenie chudoby s chorobou, ved' v libertariánskej dikcii nik osobne nenútil človeka stat' sa chudobným ani ochoriet'. Aj ked' sa človek môže ocitnút' v oboch stavoch bez pričinenia vlastnej vôle, pokial' ho cudzia osoba do tejto situácie znevýhodnenia nedostala, nikto iný ako on sám za to nemôže. V tomto poslednom význame je Berlinov opis identický s Hayekovým konceptom negatívnej slobody. V ňom však problém osobnej vol'by nehrá žiadnu rolu (Tugendhat 1993, 359 - 361).

Hayek vychádza z definície slobody ako možnosti konania jednotlivca podla svojich predstáv a plánov a rovnako ako Berlin definuje slobodu v negatívnom vymedzení ako „slobodu od okov“, čiže „nezávislost' od lubovôle ostatných“ (Berlin 1997, 59). Základná (aj politická) pointa Hayekovho výkladu v jeho práci Constitution of Liberty tkvie však úplne inde ako v zdôraznení momentu osobnej vol'by. Problém prinútenia Hayek síce tiež redukuje na „vzt'ah l’udí k iným l'udom“ (Hayek 1954, 60), ale jednoznačne bez opcie vol'by. Vo výklade negatívnej slobody ide teda o ambivalentnú dvojznačnost' termínu ,prinútenie“.

V tejto súvislosti Hayek cituje vplyvného recenzenta d’alšej svojej práce s názvom Význam slobody, jedného z duchovných otcov takzvanej chicagskej ekonomickej školy Ludwiga van Miseho. Ten na adresu románovej postavy Robinsona Crusoa, ktorý sa na úteku z pirátskeho zajatia ocitol na opustenom ostrove, napísal, že aj keby „,spadol do rokliny“ alebo „zostal uväznený v džungli“, čiže nemal by na výber, stal by s slobodným (od pirátov oslobodeným) človekom (Tamže, 61). Pre libertariánsky koncept je problém slobody identický s ,absenciou osobného prinútenia“, nie však so situáciou vol’by. Sloboda človeka znamená jedine to, že je „nezávislý od svojvol’nej moci jeho partnerov“, ako tento citát Hayek vyberá z práce van Miseho s príznačným názvom Socialismus (Yale University Press 1951, 64). Inými slovami, problém negatívnej neslobody sa nesmie v libertariánskej tradícii aplikovat' na nič iné ako na vzt’ah človeka $\mathrm{k}$ iným l’udom a vice versa. Pre libertariánsky koncept platí, že v prípade vít’azov „ekonomickej slobody“ aj v prípade obetí „ekonomického otroctva“ ide o jednu a tú istú schopnost' alebo „neschopnost” dosahovat' [vlastné, pozn. MM] ciele“, nie však o ,nedostatok slobody“" (Berlin 1997, 50). To je presne ten libertariánsky význam slobody, ktorý oprávnene kritizujú Tugendhat a Palovičová v našom kontexte. ${ }^{4}$

\section{Pozitívna sloboda (E. Tugendhat)}

Vo svojej práci Sebavedomie a sebaurčenie Tugendhat bližšie vymedzuje problém praktickej autonómie (pozitívnej autonómie) a z nej vyplývajúcej sociálnej povahy

\footnotetext{
${ }^{4}$ Pozri Palovičová, Z. (2018): Rola individuálnej zodpovednosti v liberálnych teóriách spravodlivosti, $11-38$.
} 
„neslobody“. Slobodu sebaurčenia definuje ako realizáciu a zabezpečenie jej troch zložiek - „schopnosti“ (vykonávat' činnosti), „príležitosti““ uplatnit’ ich, a nakoniec aj „osobnej vol'by“ pri výbere možnej činnosti (Tugendhat 1979, 216). V závislosti od toho sa mení aj význam „neslobody“ v l’udskom živote, ktorá v sebe zahŕňa aj neosobný vztah. Tugendhat ju charakterizuje dvoma spôsobmi, cez chýbajúcu prizmu nadobúdania „schopností“ a cez nedostatok „príležitostí “ uplatnit’ ich. Pre obe opcie platí: O neslobodnom konaní možno hovorit’ nielen v prípade jeho nanútenia inými, ale aj ked” „nemáme na výber“. To je však opačný význam „,vol’by“ ako libertariánsky „ideál zodpovednosti“. „Nemat' na výber“ znamená nemat' sociálne dostupné príležitosti ani sociálne nadobudnuté zručnosti, a teda ani autonómny nárok na určovanie života podl'a vlastných predstáv.

Vo všeobecnosti takáto „nesloboda“ znamená neprístupnost’ životných alternatív v oblasti živobytia a týka sa tak väčšiny pracovných zmlúv „slobodného sveta“, ako na to opakovane upozorňuje Tugendhat. Nikto nikoho osobne nenútil podpisovat' tieto zmluvy, deje sa to spravidla dobrovol'ne, ale v asymetrickej situácii medzi tými, ktorí musia žit' z dohodnutej práce, ked’že iný druh živobytia ako námedzná práca väčšinovo nie je $\mathrm{k}$ dispozícii, a tými ostatnými, ktorí sú v menšine, no určujú podmienky dohodnutej práce. Osobitne sa tato situácia dotýka zdravotne znevýhodnených ludí. Neslobodnými sa táto skupina stáva nielen v súvislosti $\mathrm{s}$ nedostatkom príležitostí, ale aj pre nedostatok „schopností konat" to, čo by si l'udia so zdravotným znevýhodnením zvolili, keby im $\mathrm{v}$ tom nebránila napríklad ich imobilita. Prečo by malo byt' povinnost'ou vlády a spoločnosti zabezpečit' extra služby a výhody práve pre túto menšinovú skupinu občanov?

Na tomto mieste sa oplatí pripomenút' Tugendhatovu egalitárne liberálnu koncepciu slobody v nadväznosti na jeho kritiku libertarianizmu, ktorá je blízka takzvaným capability apprach autorom. Ich spoločnou črtou je, že sa vnímajú ako moderní aritostelici. Podobne ako Amartya Sen a Martha Nussbaumová, aj Tugendhat chce bezpodmienečne prepojit' Aristotelov praktický koncept konania s Kantovým ideálom „autonómie“ a „dôstojnosti“ každého jedného človeka. Aj ked’ je reč o dôstojnosti jednotlivého človeka, takýto normatívny ideál egalitarizmu nemožno dosiahnut' individuálne, ale len cestou sociálnej kooperácie.

\section{Praktická autonómia}

Vo svojom dôležitom článku $\mathrm{k}$ l’udským právam Tugendhat odlišuje význam „autonómie“ od jej tradičného Kantovho vymedzenia „len“ ako „rozumnosti“, ked” uvádza, že „kritérium osoby“ netreba zužovat' „na racionalitu“, ale treba ho pochopit' širšie, ako praktickú ,autonómiu, schopnost’ sám sa určovat’ ako autor vlastného života“ (Tugendhat 1992, 373). Pričom toto ako (Wie) odkazuje na pôvodne 
Platónovu otázku Ako žit? Položit' si ju znamená určovat' odpovede na ňu bud' samostatne, alebo sa nechat' $\mathrm{v}$ tejto základnej otázke života riadit' odpoved’ami iných. Výraz „samostatne“ tu neznamená izolovane od ostatných, ale zodpovedne vo vzt'ahu $\mathrm{k}$ ostatným l’udom, $\mathrm{k}$ sebe samému a k činnostiam, ktoré ja ako konkrétna osoba vykonávam. Počnúc Kantom sa tento antropologický fenomén nazýva vzt’ahom „autonómie“ (samostatnosti) a „heterenómie“ (nesamostatnosti) pri určovaní vôl'ového života. ${ }^{5}$ Tugendhatom zdôraznená aristotelovská dimenzia autonómie ako samostatne osvojenej a vykonávanej činnosti, pričom od stupňa jej zvládnutia závisí úcta a sebaúcta človeka, otvára nový rozmer pochopenia l’udského života ako činnosti, ktorú si treba ako môj alebo tvoj život vcelku tiež osvojit' - lepšie alebo horšie, respektíve inak zvládnut'. Tento rozmer sa týka každého l'udského života, aj toho so zdravotným postihnutím. Kantovský problém „úcty“ a „dôstojnosti života“ tak získava pozemsky dynamickú a v čase a priestore sa odohrávajúcu podobu. Čo však mení život l'udí so zdravotným postihnutím na hodný nášho rešpektu a uznania? A ktorý prístup im takýto rešpekt a uznanie mení na diskriminačné zneuznanie a súčasne zneváženie statusu l'udskej bytosti v kritickej situácii?

Pre filozofov typu Tugendhat, Sen alebo Palovičová je odpoved'ou odkaz na Kantov termín „dôstojnost'“. Ten istý kl'účový termín možno nájst' v Medzinárodnom pakte o hospodárskych sociálnych a kultúrnych právach Organizácie spojených národov, kde sa hovorí o „inherentnej dôstojnosti“ človeka, alebo tiež v Základnom zákone Nemeckej spolkovej republiky, kde sa hned’ v prvom článku vyzdvihuje dôstojnost’ človeka ako „nedotknutel’ný základ““. ${ }^{6}$ Bol to práve Kant, ktorý videl úzku

\footnotetext{
${ }^{5}$ Paradoxne úsilie „robit’ to, čo je najlepšie“ predpokladá jednak osobný postoj, prekonávajúci vlastnú afektívne založenú pasivitu, ktorý Tugendhat neskôr nazve „egocentritou“ a vyjadrí tvrdením „záleží na mne“. No súčasne sa opiera o nadosobnú platnost' skupinových noriem, na základe ktorých môžu sa l'udia môžu sami identifikovat' ako „obuvníci, filozofovia, hráči na citaru“, ktorí bud’ vynikajú ako dobrí hráči, obuvníci atd’., alebo utŕžia posmech a neúctu za to, že svoje činnosti nezvládajú tak, ako by mali. Zásadný význam vzt’ahov kantovskej „autonómie“ a „heteronymie“, akú mu Tugendhat pripisuje, vyplýva z ambivalentnosti takto naznačeného pojmu „uznania“, s ktorým pracuje vo vlastnej terminológii. Len v činnostiach, na ktorých človeku záleží a ktorých povaha sa súčasne opiera o skupinové nadosobné kritériá, sa odohráva pre Tugendhata typicky moderný konflikt medzi kolektívnymi očakávaniami, vzhl'adom na autonómiu človeka danú heteronómnymi silami verejnosti a schopnost'ou človek robit' vec čo najlepšie, ktorý predpokladá zodpovedný, teda na kolektívnych tlakoch autonómny, čiže nezávislý prístup $k$ možnostiam vlastného konania. Moment vzájomného „uznania“ môže byt’ nástrojom „diktatúry verejnosti“, čiže zabudnutia vlastnej zodpovednosti vo zvyčajných očakávaniach vlastnej alebo cudzej skupiny. Alebo sa moment ,uznania lepších možností konat" ocitá v konflikte $\mathrm{s}$ týmito odl'ahčujúcimi skupinovými konvenciami a stáva sa momentom sebauznania $\mathrm{v}$ tej podobe, $\mathrm{v}$ akej sú tieto vždy niekým konkrétnym vykonávané činnosti hodné uznania vo vlastných alebo cudzich očiach - nezávisle od ich faktického aplauzu alebo znevažovania zo strany iných. Porovnaj prvú čast' poslednej práce E. Tugendhata Vzt'ah $k$ sebe samému $(2006,3$ - 88).

${ }^{6}$ Sémanticky odkaz na Kanta nemá prekryt' skutočnost', že termín „l’udská dôstojnost'“ sa v klasických deklaráciách l’udských práv z 18. storočia - francúzskej a americkej - nespomína.
} 
súvislost' medzi termínom „dôstojnosti“ a morálnym „rešpektom“ voči každému človeku. Ak rešpektujme, čiže uznávame človeka ako človeka nie pre jeho úžitok, ale na základe jeho dôstojnosti, rešpektujeme zároveň jeho autonómiu. Ak sa autonómia a spôsobilost' človeka žit' samostatný život podl'a vlastných schopností a predstáv nerešpektuje, namiesto sebaurčujúcej slobody musí byt' takýto človek určovaný v svojich životných možnostiach závislost'ou od svojej životnej situácie, presnejšie povedané povahou spoločnosti, v ktorej už vždy žije s inými. A to sa deje v modernom osvieteneckom ponímaní bud' ako výchova k schopnosti viest' svoj život vo vzt’ahu $\mathrm{k}$ iným a $\mathrm{k}$ sebe samému v symetrických vzt'ahoch sebaúcty a úcty $\mathrm{k}$ inému alebo vo vzt’ahoch $\mathrm{k}$ sebe a iným, založených na asymetrických vzt'ahoch moci zneuznávat' iných alebo skupiny iných a odopierat' im právo na rovnaké uznanie.

Tugendhatovo praktické stanovisko k otázke autonómie sa opiera o jej radikálne rozšírenie z ríše vedomia do praktického života $\mathrm{v}$ podobe práva na uskutočňovanie samostatného života pre každého vrátane zdravotne znevýhodneného človeka - v rámci jeho individualizujúcich možností. To, že v prípade l’udí so zdravotným postihnutím bude táto samostatnost' života ako podmienka egalitárnej úcty znamenat' iné nároky na získanie spôsobilosti a garantovanie iných príležitostí uplatnit' ich ako u ostatných, ešte neznamená, že nejde o ten istý normatívny ideál rovnosti práv. Ich dnešným normatívnym konkurentom a opakom je, ako sme už ukázali, libertariánský koncept „neslobody“ ako osobného nátlaku z cudzej vôle. Ako potom konkrétne pochopit' koncept ludských práv, ktorý zahíňa požiadavku praktickej autonómie a podmienku jej egalitárnej možnosti v podobe ekonomických a sociálnych práv? Takýto koncept l’udských práv viaže na seba verejne garantovanú kapacitu nadobudnutia „,ýznačnej činnosti“ a sociálne garantovanej príležitosti uplatnit' ju v špecifickom kontexte l’udí so zdravotným znevýhodnením.

\section{Pozitívne verzus negatívne práva}

Východiskom je koncept autonómie ako praktickej nezávislosti, ktorý v minimálnej verzii zahŕňa nezávislost' od životných okolností ako podmienku nadobúdania a uplatňovania vlastných schopností pri zabezpečovaní živobytia pre seba a svojich blízkych. Takáto nezávislost' od životných okolností predpokladá nárok na pomoc zo strany štátu (spoločnosti) pre tých, ktorým chýbajú zdroje, príležitosti a spravidla aj sociálne zručnosti ich nadobúdania. Pre vlastníkov sebestačných zdrojov (majetku), ktorí sú starí, chorí alebo zdravotne postihnutí, je to zbytočná potreba - vystačia si sami. Tradičný argument, ktorý vyrad’uje takéto právo na pomoc zo strany štátu, sa opiera o rozlíšenie negatívnych a pozitívnych práv. Klasické liberálne práva sú vo všeobecnosti chápané ako požiadavka nezasahovania vlády do sféry individuálnej autonómie. Ekonomické l’udské práva sú zasa vo všeobecnosti pochopené ako pozitívne práva, 
prostredníctvom ktorých sa uplatňuje záväzok vlády poskytovat' služby a kvalifikovanú pomoc vrátane zabezpečenia zdrojov ich financovania. V tejto súvislosti sa vynárajú dva druhy problémov pri rozlíšení pozitívnych a negatívnych práv.

Primát a výlučné postavenie negatívnych práv v l’udskoprávnej agende vyplýva z pochopenia l'udského života ako vlastníctva (držby) osoby a súčasne postulátu nedotknutel'nosti súkromného vlastníctva tak, ako to v 18 . storočí vyplynulo z novovekého konceptu prirodzených práv. L'udské práva sú preto, prirodzenými právami, lebo nimi ludia disponujú v predspoločenskom, čiže prirodzenom stave, a v tomto zmysle platia už pred konkrétnou spoločnost'ou a mimo nej. $Z$ toho dôvodu sa tieto práva týkajú vzt'ahov medzi l'ud’mi, a to nezávisle od vlády. ${ }^{7}$ Takýto, podl’a Tugendhata ,teologický výklad ludských práv“ inštitucionalizuje princíp všetkých vlád tak, ,aby [len] chránili tieto práva““ ${ }^{8}$ Ked’že tieto práva platia od prírody, a zároveň ako „neodňatel’né“ a ,nescudzitel'née sú človeku prepožičané ,z vyššej moci“, všetky vlády majú v zásade výlučne (negatívnu) povinnost' ochraňovat' ich, nie však konštituovat' nové - pozitívne práva, a tým garantovat' sociálne a ekonomické práva pre svojich občanov. V perspektíve 18. storočia je teda zrejmé, že novoveká tradícia l’udských práv ako prirodzených práv jednotlivcov sa vylučuje s konceptom pozitívnych práv, pretože ich garantom a nositel'om môže byt' len pozemská vláda, nie však izolovaný jednotlivec. ${ }^{9}$ No v novovekej tradícii prirodzených práv sú l'udské práva pochopené primárne ako práva na ochranu pre zásahmi vlády a štátu.

\section{Lockov problém vlastníctva}

S týmto predspoločenským statusom l'udských práv súvisí, iný zásadný problém, ktorý spočíva v dvojjedinosti práva a nedotknutel’nosti života a vlastníctva. Historicky najvplyvnejším autorom l’udskoprávnej dvojjedinosti práva na život a práva na vlastníctvo je John Locke. V Druhom pojednaní o vláde Locke rozvíja svoju teóriu prirodzeného stavu, čím zviditel'ňuje pôvodné práva človeka vo význame vlastníctva osoby a výsledkov jeho práce. ${ }^{10}$ Už $§ 4-6$ zahŕňajú vymenovanie prvých slobôd, ktoré neskôr explicitne formujú právo človeka na slobodu narábania so svojou osobou a majetkom podl’a

\footnotetext{
${ }^{7}$ Podobne to možno čítat' v Deklarácii nezávislosti Spojených štátov: „Pokladáme za samozrejmé pravdy, že všetci l'udia sú stvorení ako rovní a svojím stvoritel'om sú obdarovaní určitými neodcudzitel'nými právami, medzi ktoré patrí právo na život, slobodu a budovanie osobného št’astia; že pre zabezpečenie týchto práv sú medzi l'ud'mi ustanovované vlády, odvodzujúce svoju právnu moc od súhlasu tých, ktorým vládnu“.7 Takýto, podl’a Tugendhata „teologický výklad l’udských práv“ inštitucionalizuje princíp všetkých vlád tak, „aby [len] chránili tieto práva“. Citované podl’a http://www.konzervativizmus.sk/article.php?4432

${ }^{8}$ Porov. Tugendhat $(2003,266)$.

${ }^{9} \mathrm{~K}$ intersubjektívnemu pochopeniu zodpovednosti pozri Smreková (2010, 893 - 906).

${ }^{10}$ Porovnaj dodnes inšpiratívny náčrt Lockovej teórie nadobudnutia vlastníctva (Nozik 1973, 169 174). V domácom kontexte podrobne pozri Manda $(2015,61-82)$.
} 
vlastného uváženia, ${ }^{11}$ ked’že zdrojom vlastného majetku každého človeka je jeho práca. Základným predpokladom tejto schémy je pôvodne teologická idea, že Boh ako pôvodca stvoril svet tak, aby „,spontánna ruka prírody“ zabezpečila dostatok všetkého, a to nielen pre niektorých, ale pre všetkých l'udí stvorených na obraz Boží. Dôsledkom takejto úvahy je zásadná politicko-filozofická ilúzia prirodzeného stavu, v ktorom sú všetci už vlastníkmi zdrojov na samostatné živobytie a v tomto sebestačnom stave zostávajú aj ako budúci občania po fiktívnom podpise spoločenskej zmluvy. Ked’že v princípe každý je schopný postarat' sa o seba v prirodzenom stave, nerovnosti v bohatstve a chudobe nie sú problémom vlády, ked’že každý je už pôvodne „vlastníkom“ podla výsledkov „práce jeho tela a diela jeho rúk“. Podla tejto koncepcie slobody sa logicky „nesloboda“ určuje zasahovaním inej osoby alebo l’udí do môjho života. Všetky ostatné prekážky sú vecou zodpovednosti indivídua za seba. ${ }^{12}$ To, čo platí vo fiktívnom prirodzenom stave ako dostatok pre každého, neplatí v reálnom čase asymetricky rozdelených zdrojov a majetkovo nerovnovážne zadaných podmienok živobytia „tých hore“ a „tých dolu“.

Preto môže Tugendhat na adresu kontraktualistickej tradície prirodzeného práva zhrňujúco konštatovat': Libertarianizmus ,je morálkou silných [...], hoci silní so slabými budujú usporiadanie spoločnosti založené na [dobrovol’nej, pozn. MM] zmluve a potom sa na výsledok dívajú ako na morálku so rovnakými právami“ (Tugendhat 1993, 275). Slabí a bezmocní tu nemajú kompenzačné práva. Ak skombinujeme východiskovú fikciu sveta v teórii prirodzených práv ako stav dostatku všetkého pre všetkých so záujmovo orientovaným spôsobom fungovania modernej trhovej spoločnosti, tak neprekvapí Tugenhatov d'alší odkaz, že takáto spoločnost' vychádza z ilúzie, podl’a ktorej „spoločnost' pozostáva len z dospelých práceschopných mužov", ktorí už majú zručnosti postarat' sa o seba (svoje rodiny), a preto na to vždy nájdu príležitost', pokial' nie sú leniví, takže solidarita a potreba pomoci je viac-menej vecou individuálnej charity a súcitu, určite však nie záväzkom štátu, pretože kto je bez prostriedkov, „môže si za to sám“ (Tamže).

\footnotetext{
11 „Aj ked' zem a všetky nižšie stvorenia sú spoločné všetkým l’ud’om, predsa má každý človek vo vlastníctve svoju osobu. Na to nemá nikto iná právo, iba on sám. Práca jeho tela a dielo jeho rúk, sú, môžeme povedat', tiež právom jeho“"(Locke 1836, 116).

12 Tatiana Sedová si všimla túto ,jánusovskú odvrátenú tvár l’udských práv“ a plným právom upozorňuje na ideologickú zneužitel'nost’ tohto konceptu s aktuálnym upozornením, že ochranu l'udských práv nemožno zredukovat' na ideológiu globálneho turbokapitalizmu, pretože - ako normatívny koncept sa pôvodne týka postavenia všetkých, aj sociálne zranitel'ných členov v modernej spoločnosti. Bližšie pozri Sedová (2018). V habermasovskom kontexte pozri Sedová (2012, 141 - 152).
} 


\section{Právo na život verzus právo na vlastníctvo}

Alternatívny výklad vztahu ,práva na život“ a ,práva na vlastníctvo“ ponúka Tugendhatov prístup, ktorý vychádza z Kantovho pojmu „dôstojnosti“ každého človeka a jeho antropologického ekvivalentu „svedomia“. Tugendhatov koncept „etiky úcty“ však predpokladá prekonanie Kantovho dualizmu inteligibilno-večného sveta (mundus intelligibilis) a zmyslovo-dejinného sveta (mundus sensibilis). Klasickú liberálnu teóriu vlastníctva kritizuje za jej normatívne východisko: fikciu prirodzeného stavu s predstavou neobmedzených zdrojov pre samostatný život každého jej člena a so zabezpečenou majetkovou symetriou. Podla nemeckého povojnového filozofa sa rodíme do reálneho sveta už asymetricky rozdelených majetkových pomerov, príjmov a závislostí, ktoré vytvárajú stav prvotnej heteronómie v určovaní vlastných životných šancí. Predovšetkým každé právo, aj právo na vlastníctvo, možno uplatnit' len v spoločnosti, nikdy nie však vo fikcii predspoločenského vzt’ahu. Naopak, každé právo, aj právo na vlastníctvo, je možné len ako intersubjektívne zdielaný záväzok v spoločenstve s inými. Základnou Tugendhatovou otázkou teda nie je dilema ,indivíduum“ verzus „spoločenstvo“, ale aké spoločenstvá a aký druh kooperácie v ňom bude dominovat' (Tugendhat, 1992, 359).

Z toho pohl'adu je väčšina l’udí aj v dnešnej spoločnosti narodená do sveta nerovnosti v získavaní schopností a v nerovnakých príležitostiach uplatnit’ ich, teda v situácii, ktorú Tugendhat opät’ presne nazýva situáciou „ekonomickej neslobody“ l'ud'om nemusia chýbat' politické slobody, a predsa prakticky nemajú „na výber“. ${ }^{13}$ Chýba im často faktická sloboda uplatnit' svoje právne možnosti. Tugendhat je dobre poučený nemeckými dejinami, preto pokladá vzt’ah ,ekonomickej neslobody“ $\mathrm{k}$,občianskym slobodám“ za klúčcový problém politickej udržatel'nosti l'udských práv.

To, čo vo všeobecnosti chýba, je praktická autonómia, ktorá v tomto prípade znamená nielen ochranu pred materiálnou núdzou, ale - a to je klúčcová Tugendhatova myšlienka - zabezpečenie vymáhatelných práv na nadobudnutie tých zručností, ktoré „tým dolu“ umožnia zvládnut' nejakú činnost' tak, aby nemuseli byt' odkázaní na iných, respektíve aby sa miera tejto odkázanosti čo najviac minimalizovala „Zaistenie minimálneho pozitívneho vol'ného priestoru, ktorý by všetkým l'ud’om umožnil, aby sa postarali o svoje blaho, nakol'ko im to ich situácia dovolí, sa javí rovnako základným právom ako právo na telesnú nedotknutel'nost"“ (Tugendhat 1993, 360). Aj tu musí byt' nárok na dôstojnú existenciu zabezpečený tak, ,aby sa dotyční l'udia

13 „Z celosvetového hl'adiska žije vel'ká čast' l'udstva v ekonomickej neslobode, to znamená, že l'ud'om tu chýba prístup k zdrojom, ktoré by im umožňovali bud' sa vôbec udržat' na žive, alebo tak činit' l'udsky dôstojným spôsobom... Táto nesloboda nespočíva [...] v tom, že sa určitej časti l'udí sa nedostáva zdrojov, ale v tom, že existujúce zdroje sa nachádzajú v rukách bohatých, ktorí sú vo svojej držbe zaistení z morálneho hl'adiska jednostranným trestným právom a získavajú mocenskú pozíciu, na základe ktorej môžu z chudobných nad’alej t’ažit““ (Tugendhat 1993, 277). 
naučili a mohli vykonávat' činnosti, ktoré sú im v ich životnej situácii dostupné“ (Tamže). Negáciou tohto nároku je principiálna nesamostatnost' ako faktická závislosti od iných,.., ,[ked' pomoc] zájde príliš d’aleko..., skoro každý starý, chorý a alebo zdravotne postihnutý človek [ju] vníma ponižujúco“ (Tamže, 361). Základné ludské právo osvojovat' si činnosti nevyhnutné na dôstojný život l'udí so zdravotným znevýhodnením sa týka perspektívy zvládania života čo najsamostatnejšie do tej miery, ako to daná situácia umožňuje.

\section{„Sloboda“ verzus ,potreba pomoci““}

Takýto prístup na základe normatívneho ideálu „pomoci k sebapomoci“ má dve normatívne závažné konzekvencie. Tugendhatova definícia „neslobody“ ako chýbajúcej sociálnej kompetencie osvojit' si zručnosti vykonávat' „význačné“ činnosti z hl'adiska možností ich aktéra, a súčasne chýbajúcej príležitosti ich uplatnenia, navádza k mylnému názoru, že ide o prehíbenie a rozšírenie sféry „slobody“. Podobný postoj Tugendhat zastával ešte v práci Sebavedomie a sebaurčenie, kde spracoval tento základný koncept slobody. ${ }^{14}$ Vo svojich o pätnást' rokov mladších Prednáškach o etike však Tugendhat pod priamym vplyvom A. Dworkina, a najmä A. Shua, zásadne limituje liberálny prístup k l’udským právam práve odkazom na agendu l’udských práv pre osoby so zdravotným znevýhodnením: $\mathrm{v}$ ich prípade motívom uplatnenia nároku na pomoc nie je rozširovanie „slobody“ ako schopnosti určovat' vlastný spôsob života. Primárnym dôvodom uplatnenia osobitých výdavkov a osobitých verejných priestorov je „potreba pomoci“ - v krajnom prípade aj vtedy, ked” sa sféra praktickej slobody, čiže kontroly nad vlastným životom nerozšíri.

V tomto zmysle to už nemôže byt' liberálny odkaz na recipročnú úžitkovost' slobodných zdravých a dospelých l'udí vo fikcii prirodzeného stavu, ale primárne zohl'adňovanie záujmov všetkých tých l’udských bytostí, ktorým k realizácii podl'a možnosti čo najsamostatnejšieho života chýbajú „zručnosti a zdroje“ (Tugendhat 1993, 359). Práve u l'udí so zdravotným postihnutím sa ,potreba pomoci“ nemôže zakladat' na tom, či je ich hendikep spôsobený chybou, napríklad nerozvážnym skokom do plytkej vody v bazéne, alebo ju pri nehode zavinil niekto iný. Libertariánsky výklad „nezavinenej“ neslobody ako výsledku absencie „osobného prinútenia“, čiže obmedzovanie moje slobodnej vôle niekým iným, tu nedáva žiadny význam. Práve neschopnost' vykonávat' osamostatňujúce činnosti, a nie cudzie či vlastné zavinenie, robí l'udí so zdravotným postihnutím „neslobodnými“ nezávisle od toho, ako sa v tejto neschopnosti ocitli.

Pomocou takto pochopenej „neschopnosti“ môže aj termín „slobody“ získat' jasný „pozemský“ zmysel, totiž tak, že podla Tugendhata je sloboda len ,jednou zo základ-

\footnotetext{
${ }^{14}$ Pozri Tugendhat $(1979,215-222)$.
} 
ných l'udských potrieb, nie však jedinou a ostatným potrebám človeka nadradenou potrebou“ (Tamže). Tugendhat upozorňuje v tejto súvislosti práve na sémantickú zmenu právneho jazyka, ktorý v ústavných povojnových textoch nahradil termín „slobody“ odkazom na „’udskú dôstojnost“". Adresátom sociálnych a ekonomických práv nie je teda jednotlivec, ale v primárnej odkázanosti na pomoc je ním spoločenstvo l’udí, ktoré sa chápe egalitárnym spôsobom ako spoločenstvo vedené etikou úcty pred každým l'udským životom.

Nech už ide o deti, starých l'udí či l'udí so zdravotným znevýhodnením, ani jedna skupina nespíña pôvodné kantovské kritérium „rozumnosti“ a „sebavedomia“, ktoré robia jednotlivca subjektom l’udských práv. Čo v prípade, ked' si nevie pomôct’ sám, lebo nevie o sebe rozhodovat' prirodzene, spontánnym spôsobom, ako napríklad deti $\mathrm{s}$ autistickým spektrom ochorení? Práve v tomto prípade treba „dôstojnost““ človeka postihnút' v perspektíve samostatného alebo osamostatňujúceho života, ktorý síce môže de facto chýbat' l'ud'om so zdravotným postihnutím, ale tento autonómny rozmer l'udskej bytosti zostáva normatívnou perspektívou pochopenia l'udskej pomoci ako „pomoci k svojpomoci“. Na druhej strane je postihnutý človek v posilňovaní potreby vlastného života odkázaný na finančné a logistické možnosti solidarizujúceho spoločenstva, pretože bez jeho pomoci by nemusel prežit', alebo by žil kvalitatívne horší - nedôstojný život.

Takéto egalitárne pochopenie každého člena spoločnosti ako subjektu rovnakých práv sa musí ako vzájomne uznané a navzájom požadované rešpektovanie l'udskej dôstojnosti premenit' na kolektívne udržiavané sebapochopenie, ktoré sa nedá nahradit' pravidlami férovo nastavených inštitúcií, čiže odkazom na ,one size fits all“ politiky „transcendentálneho inštitucionalizmu“. ${ }^{15}$ Práve preto, že Tugendhat zámenou pojmu „slobody“ za ,l'udskú dôstojnost"“ rozširuje rozsah ,autonómie“ z kantovskej „rozumnosti“ na schopnost’ samostatného života, môže aj Kantov pojem „úcty“ ako „bezpodmienečnej hodnoty“ osoby zbavit’ jeho metafyzickej sebestačnosti a nezávislosti na časovo-priestorovej realite. „L'udskú dôstojnost'“ možno realizovat' primárne v tomto svete (a nie v tom po ňom), a to tak, že zdravotne znevýhodnení l'udia (samozrejme, nielen oni) majú / môžu žit' v „l'udsky dôstojných“ podmienkach (Tugendhat 1993, 362). Majú, ale nemusia, pokial' sa spoločenstvo od nich odvráti a neberie ich na vedomie. Zároveň sa takéto „l'udsky dôstojné podmienky“ nedajú vyčerpat' odkazom na materiálno-servisné „existenčné minimum“.

Takéto materiálne zdroje sa musia totiž premenit' aj v prípade l'udí, ktorí nebudú môct' viest' plnohodnotný samostatný život, na schopnosti / príležitosti „nadobudnút'

${ }^{15}$ Porov. Palovičová (2018, 12 ff). 
a vykonávat' činnosti primerané ich vlastným možnostiam“ (Tamže, 361). Takýto pojem „„cinnosti“ hĺbkovo presahuje význam zárobkovej činnosti a nedá sa pochopit’ v modernom vymedzení práce ako komodity - tovaru na predaj. V krajnom prípade totiž často ide o l'udí, ktorí si sami nemôžu pomôct', aj keby im v ideálnom prípade bolo zaistené právo na prácu. Pre hendikepovaných l'udí takáto „činnost"“väčšinovo znamená primárne učit' $s a$ osvojit' samostatne si uspokojovat' potreby a osvojovat' si socializačné pravidlá života s inými, ktoré u väčšiny fungujú spontánne a „od prírody“. No aj ked' za pomoci finančne náročných terapií tento level vlastnej socializácie zvládnu a sú schopní samostatne žit's ostatnými, takíto l'udia často nemajú príležitost' ani možnost' uplatnit' tieto sociálne spôsobilosti. Krajným opakom tejto osamostatňujúcej perspektívy je pasívna - doživotná - závislost' od iných l'udí alebo inštitúcií.

\section{Záver}

To, čo sa označuje termínom pozitívna diskriminácia (affirmative action), teda zvýhodnenie menšiny za účelom reálneho odstránenia diskriminácie, predpokladá rozšírenie „autonómie“ aj na životy tých l'udí, ktorí sami nie sú prvotne schopní si ju zabezpečit', a to osobitne v prípadoch, ktoré nezodpovedajú tradičnému ideálu „rozumnosti“ a „sebavedomia“. To však neznamená, že tento normatívny ideál ,autonómie“ nemožno, napríklad prostredníctvom včasnej terapeutickej intervencie v prípade detí s poruchami autistického spektra alebo inými vývinovými poruchami v značnej miere realizovat'. Opakom takejto životnej samostatnosti je jej popretie asymetrickou závislost’ou a rizikom pasívneho živorenia bez uznania a rešpektu v sociálnom ústave. Ak sa osvojovanie činností, ktoré osamostatňujú v danej situácii život zdravotne postihnutého človeka, tento „činnostný“ aspekt pochopí v aristotelovskom zmysle ako zdroj rešpektu voči človeku a primárne aj ako potencionálny zdroj sebaúcty, tak potom možno povedat', že princíp dôstojného života dostal prednost' pred právom na nedotknutel'nost' vlastníctva Adresátmi práv a týchto komplexných požiadaviek sú primárne tí, ktorí verejnú pomoc potrebujú, pretože im, a často aj ich rodičom, inak nezastáva nič iné ako nedôstojné živorenie.

Tým je však tematizovaný aj základný normatívny problém a realpolitická prekážka zavádzania „,sociálnych základných práv“: obmedzenie klasického negatívneho práva, práva na vlastníctvo. Pre libertariánskych zástancov Lockovej a Nozikovej idey pôvodu majetku vlastnou šikovnost'ou a prácou musí byt' každé prerozdel'ovanie „krádežou“ (Tamže), alebo - ako sa emotívne vyjadril Nozik - požiadavkou „nútenej práce“ v prospech „nezamestnaných hipíkov“ (Nozik 1973, 167). Pre tých, ktorí podobne ako Tugendhat a Palovičová uznávajú sociálne práva ako základný spôsob riešenia „ekonomickej neslobody“, však postavenie slabých a znevýhodnených l’udí 
musí byt' pochopené zásadne inak. Tak, aby „právo na majetok [bolo nutné] obmedzovat'v tej miere, v akej porušuje práva ostatných občanov" (Tugendhat 1993, 362). V tomto bode sa však zásadne mení normatívna perspektíva výkladu l’udských práv. Namiesto nadradeného primátu práva na osobnú slobodu a sebarealizáciu, vo vzt’ahu ku ktorému sú aj ostatné práva prostriedkom jeho naplnenia, sa pojem rovnosti v otázke ekonomicko-politickej slobody všetkých členov spoločenstva stáva kritériom, ktorému treba podriadit', alebo podl'a neho obmedzit' aj práva na ochranu individuálnej slobody, rozumej vlastníctva. ${ }^{16}$

Tieto dva normatívne ideály individuálnej slobody a rovnosti sú z individuálneho hl'adiska jednotlivca hodnotami, ktoré si zásadne konkurujú, pričom poslednými motívmi sú egoizmus na jednej a schopnost' obmedzit' sa $\mathrm{v}$ mene rovnakého rešpektu a uznania každého l'udského života na druhej strane. Eliminovanie choroby a hladu ako krajných podôb l'udskej núdze nemožno pokladat' za rozširovanie sfér slobody, ale za vyjadrenie ich bazálneho predpokladu, bez ktorého l'udia nie sú schopní realizovat' ich právne garantované ústavné slobody. ${ }^{17} \mathrm{~V}$ tomto rozmere ,právo na život“ a „právo na vlastníctvo" sa už nedajú automaticky pochopit' ako vzájomne sa doplňujúce l'udské práva, ale treba ich tematizovat' ako prítomnost' dvoch zásadne odlišných normatívnych konceptov l'udských práv - libertariánsko-antiegalitárneho a egalitárne-demokratického. Táto normatívna kolízia naznačuje to, čo na inom mieste vo svojej kritike osvietenstva presne pomenoval škótsky konzervatívny myslitel' Alsdair MacIntyre. Jeho klúčová téza hovorí, že v základoch modernej spoločnosti nie je „konsenzus, ale konflikt" weberovsky nezlučitel'ných hodnotových poriadkov - vzájomne sa vylučujúcich predstáv spravodlivosti (Porov. MacIntyre 2004, 294).

Tugendhatov apel na egalitárne sa chápajúce spoločenstvo rozumných l'udí v jeho Prednáškach o etike ${ }^{18}$ je vedomou odpoved'ou na túto konzervatívnu kritiku osvietenstva, a to $\mathrm{v}$ híbke uvedomenia si aj dnes živej civilizačnej alternatívy k egalitarizmu - skúsenosti s antiegalitárne založeným spoločenstvom silných voči slabým, vyvolených rasou voči ostatným menejcenným.

\section{Literatúra}

BERLIN. I. (1997): Dva pojmy slobody. In: Kiss. J. (ed.): Současná politická filozofie. Praha: Oikoymenh, $47-101$.

\footnotetext{
${ }^{16}$ Významný Tugendhatov žiak a profesor praktickej filozofie na Freier Universität v Berlíne, kde pôsobil aj jeho učitel', to napísal nekompromisne: „Právo na podl'a možnosti čo najväčšie subjektívne priestory slobody sa nedá zabezpečit' bez distributívnej rovnosti, pretože sloboda, prípadne práva slobody sú osobitým prípadom aplikácie distributívnej rovnosti“ (Gosepath 1978, 163).

${ }^{17}$ Pozri Gosepath $(1978,163$ - 171).

${ }^{18} \mathrm{~V}$ tejto práci venoval tri prednášky kritike Mac Intyrovho konceptu cnosti. Porovnaj Tugendhat $(1993,197-250)$.
} 
HAYEK, F. W.(2011): The Constitution of Liberty. The Collected Works of F. A. Hayek, Vol. XVII, Chicago: The University of Chicago Press.

GOSEPATH, S. (1998): Zu Begründungen sozialer Menschenrechte. In: Gosepath,S. - Lohmann, G. (eds.) Philosophie der Menschenrechte. Frankfurt: Suhrkamp, 147 - 173.

HONNETH, A. (2018): Právo svobody. Nárys demokratické mravnosti. Prel. B. Horyna. Praha: Filosofia.

LOCKE, J. (1823): Two Treatise of Goverment. The Works of John Locke, Vol. V. London: Printed for Thomas Tegg; W. Sharpe and Son; G. Offor; G. and J. Robinson; J. Evans and Co.

MACINTYRE, A. (2004): Ztráta cnosti. Praha: Oikoymenh.

MANDA, V. (2015): Človek, vlastníctvo a sloboda vo filozofii Johna Locka. In: Manda, M. St’ahel', R. - Pružinec, T. (eds.): Človek, sloboda, vlastníctvo. Bratislava: Iris, 61 - 81.

NOZIK, R. (1973): Distributive justice. In: Anarchy, State and Utopia. Blackwell 1973, 149 - 182.

PALOVIČOVÁ, Z. (2018): Rola individuálnej zodpovednosti v liberálnych teóriách spravodlivosti. In: Smreková, D. (ed.): Podoby zodpovednosti. Filozofické reflexie o aktuálnych spoločenských problémoch. Bratislava: Iris.

SEDOVÁ, T. (2012): Poznámky k Habermasovým východiskám komunikačnej teórie konania. Filozofia, 67 (9), $143-151$.

SEDOVÁ, T. (2018): Jánusovská tvár l'udských práv: medzi l'udskou dôstojnost'ou a právom mat' práva. Filozofia, 73 (4), $318-328$.

SMREKOVÁ, D. (2010): Čo znamená prevziat' zodpovednost? K pojmu imputácie v súčasnej etike. Filozofia, 65 (9), 893 - 906.

TUGENDHAT, E. (1984): Bemerkungen zu einigen methodischen Aspekten von Ralws' Theorie der Gerechtigkeit. In: Probleme der Ethik. Stuttgart: Reclam Verlag, 11 - 33.

TUGENDHAT, E. (1989): Die Hilflosigkeit der Philosophen angesichts der moralischen Schwierigkeiten von heute. In: Tugendhat, E. (1992) (ed.): Philosophische Aufsätze. Frankfurt: Suhrkamp, $371-385$.

TUGENDHAT, E. (1979): Selbstbewustsein und Selbstbestimmung. Frankfurt: Suhrkamp.

TUGENDHAT, E. (1993): Vorlesungen über Ethik. Frankfurt: Suhrkamp.

TUGENDHAT, E. (2006): Egozentrität und Mystik. Eine antrophologische Studie München: Verlag C. H. Beck.

Príspevok vychádza v rámci projektu VEGA č 2/0110/18 Genealógia svedomia, fenomenalita konania a existencia $v$ dialógu s inými.

Martin Muránsky

Filozofický ústav SAV

Klemensova 19

81364 Bratislava

Slovenská republika

e-mail: muransky.ma@gmail.com

ORCID ID: https://orcid.org/0000-0002-1986-0460 